\title{
The Role of Women and Girls in the Eyes of Islamic State: A Content Analysis of Dabiq and Rumiyah Magazines
}

\author{
Marta Sara Stempień \\ Institute of Security Studies, Siedlce University of Natural Sciences and Humanities, Siedlce, Poland \\ Corresponding author: marta.stempien@uph.edu.pl
}

Submitted: 27 January 2021 | In revised form: 18 May 2021 | Accepted: 18 August 2021 |

Published: 4 October 2021

\begin{abstract}
The article analyses a large content of the English-language magazines Dabiq and Rumiyah. They provide a significant amount of content for research on the role of women (mostly Western) in jihadi terrorism. The author attempts to understand the leading themes related to women and girls exploited in these sources. A major objective is to discover and understand the Islamic State's approach towards women and girls, as well as their role in the self-proclaimed caliphate. To reach this goal, quantitative and qualitative content analysis is used. Research confirmed that both magazines contain special sections for women and interviews with female followers. IS has proved to be relatively tolerant of the inconsistence of its ideology. The author acknowledges that the magazines discussed were inconsistent, or rather variant in the application of its message. This is particularly true to the role of women.
\end{abstract}

Keywords: gender; Islamic State; jihadism; terrorism; women

\section{Introduction}

In recent decades, more attention is being paid to female involvement in terrorist groups, both by scholars and by public opinion. In reality, as Karla J. Cunningham (2003) [1] states "there are clear trends toward women becoming more fully incorporated into numerous terrorist organizations." In the past, most of the attention focused on male activity in terrorism. In stereotypical thinking, the perpetrators of terrorist violence were men while women were usually situated in the role of victims ([2], pp. 201-218). This assumption of gender roles does not reflect the reality of Islamic State modus operandi. Women and even girls in this structure play diverse roles, from supporters, wives, mothers, slaves to positions of warriors, authority, and even leadership. However, it is true that females are a minority in terrorist groups, but their role seems to evolve. The shift towards more active female involvement can be caused by intensified anti-terrorism measures. They force groups to rely on their female members, for example, in suicide operations ([3], pp. 4,29), [4]. In the case of Islamic State territorial expansion, they also helped instate building, producing and disseminating propaganda materials. They also worked in the administrative and "public" structures of the caliphate.

Women play an important role in the tactical activities of terrorist groups. A structure that promotes women's subjugation and sexual slavery also seemingly offers women tools of empowerment. For example, by showing the educational opportunities available to women in IS-controlled areas, it presents a narrative that may appeal to women as attractive and even empowering. In this way IS deceives women. Anne Speckhard (2008) [5] states that females self-recruitment to terror organizations derives from "motiva- 
tions inside conflict zones of trauma, revenge, nationalism, expression of community outrage and in nonconflict zones feelings of alienation, marginalization, negative self-identity, and a desire to act on behalf of those inside conflict zones (See also [6]). Also "the process of radicalization happens because of individual, social, and political dynamics, and is facilitated by the availability of computer-mediated communication" ([7], p. 506). Many authors also emphasize the role of revenge in stimulating the participation of women in terrorist activities and draw attention to the significant presence of widows among female fighters ([8], pp. 413419). Although there are many reasons that prompt women to join jihadi groups, their value for operational activities is clear. Dalton and Asal (2011) [9] identified the benefits of women's involvement in terrorist groups' activities. They described four types of benefits: support role and care giving; strategic advantage related to the general perception of peacefulness and pacifism attributed to women; martyrdom and symbolic value in suicide terrorism; reproduction, physical and emotional comfort to men members of terrorist groups. Given their appearance, they are perceived as gentle and non-threatening. By using women, the terrorists get access to previously unnoticed potential in "promoting the group's agenda, recruitment and completing missions" ([10], pp. 250-251). They also gain wider media attention, because of a more gentle physical appearance, familial background (stories of women driven to commit violence by the death of family members or the man they love). Such perception of women in mass media allows the groups to spread their ideology more effectively and attract more potential supporters.

\section{Theoretical Approach and Methodology}

The following article has the form of a case study, with the media and political approach central to considerations. The research goal is to determine whether women and girls related topics are important in the Islamic State's Englishlanguage propaganda. The article aims to investigate what roles women and girls play in IS and how much propaganda content is addressed to the female part of the audience. Although the IS has lost its territorial base, this structure continues operations in various regions of the world. Media reports from the first half of 2020 indicate that IS is recovering after a period of decline. Therefore, the threat from the IS and other violent groups to the international security is still present. Therefore, the findings of this article are intended to stimulate debate on prevention and alternative strategies to combat news on initiatives related to the radicalisation and recruitment of women. This article analyses the ways in which IS communicates its worldview to its readers, and the extent to which gender messaging were used as a mechanism to maintain power and recruitment tools. The research focuses on the period from July 2014 to September 2017, thus the period of publication of the Dabiq and Rumiyah.

Research methods that were undertaken to solve the problems include: documentary analysis, scientific literature analysis, statistical data analysis, case analysis, systemic analysis, classification, generalization, seeking to determine the principal tendencies of the IS' changes in the approach towards women and girls. To determine the main themes, quantitative and qualitative analysis were used. This study focused on text to examine changes in IS's approach over time. In a qualitative study of the content, the author assumed that magazines are one of the instruments used for radicalization (More on the radicalization processes see [11]).

The IS propaganda makes it necessary to state some specific procedures of data collection to generate relevant data/ information for content analysis. In this study, the author uses the documentary method to support the argument of academic research. Documentary research, next to survey and ethnography, is one of the three major types of social research (see [12]). The process of documentary research involves conceptualizing and assessing documents, in this study electronic magazines. The analysis of the documents is both quantitative and qualitative. The data set for this research consists of fifteen issues of Dabiq and thirteen issues of Rumiyah. All issues were downloaded from Jihadology.net and ieproject.org. The research consisted in systematic search for the keywords. All words and images related to women and girls, in their singular and plural forms (woman, women, girl, girls, female, females) were extracted, catalogued, and assigned in accordance with the section allocated to them in the magazine. In total, 616 words related to women and girls were found (see Table 5), 128 in Dabiq and 93 in Rumiyah. They were classified according to their subject matter, section type, and analysed. The distribution of words in the article types was then conducted. Similarly, all articles of both magazines were classified into types according to their titles and content focus. The distribution of article types was matched with all issues of the magazines (see Tables 2 and 4).

\section{Literature Review}

In recent years, a lot of research has been devoted to terrorism. It is no surprise that structures such as the IS are constantly in the light of researchers' interests. Among the English-language studies worth noting, one can mention: J.Stem and J.M. Berger, ISIS. The State of Terror (2015) [13] or A.B. Atwan, Islamic State. The Digital Caliphate (2015) [14]. Therefore, the increased interest in terrorist activities directly transfers into the deepening of multilayered research.

In the era of fast mass media proliferation, research on Jihadist propaganda is also intensifying. Some of these researches refer to this problem as a whole, e.g., J. Ch. Andersen and S. Sandberg, Islamic State Propaganda: Between Social Movement Framing and Subcultural Provocation [15]. Others touch a certain aspect of propaganda activity, such as English magazines. The references to the content of Dabiq and Rumiyah include articles by: T. Welch, Theology, heroism, justice, and fear: an analysis of ISIS 
propaganda magazines Dabiq and Rumiyah (2018) [16], or M. Lakomy Recruitment and Incitement to Violence in the Islamic State's Online Propaganda: Comparative Analysis of Dabiq and Rumiyah (2019) [17]. A 2019 study of Inspire, Dabiq, Rumiyah, and Gaidi Mtaani "reveals that the online jihadist magazines integrate all analyzed themes to portray their messages. The findings show certain issues implement specific themes more than others. Across the sample, the use of persuasion justified and encouraged violence. Persuasion is found in prideful examples of successful terrorist attacks and aftermath scenes of destruction. The distinct difference between the four online jihadist magazines is the persuasion of recruitment" of both men and women ([18], p. 240).

The narrow issue of the image of women and girls, their radicalization process and the analysis of online recruitment is also gaining attention. This subject regarding IS can be found in the following analyzes: L. Windsor, The Language of Radicalization: Female Internet Recruitment to Participation in ISIS Activities (2020) [7], Europol Report on Women in Islamic State Propaganda: Roles and Incentivites (2019) [19], H. Khelghat-Doost, Women of the Caliphate: The Mechanism for Women's incorporation into the Islamic State (IS) (2017) [20] or A. Søberg Aasgaard, Migrants, Housewives, Warriors or Sex Slaves: AQ's and the Islamic State's Perspectives on Women (2017) [21]. Although many of the issues related to women in the IS propaganda have been touched, still in this area, there is a lack of a quantitative analysis of women's and girls' images. Literature review shows the most comprehensive examination of Islamic States' propaganda from a gendered perspective has been examined by N. Lahoud (2018) [6] in the UN report entitled Empowerment or Subjugation: An Analysis of ISIL's Gender Messaging. However, this publication is qualitative analysis.

\section{Media Apparatus of the Islamic State: Rumiyah and Dabiq}

The Islamic State's media apparatus has been extremely developed and mainly composed of digital media: Al-Furqan Media, Al-I'tisam Media, Ajnad Media and Al-Hayat Media. It also established the A'maq news agency, Al-Bayan radio station, Tawheed television and media offices in each new province ([22], p. 88), ([23], pp. 30-31), [24]. Jihadists published a plethora of propaganda in different languages, using all modern means, including social media (See for example [25]). To increase the number of recipients, IS provided access to the information marked with the symbol \#, the so-called hashtag. The most common hashtag used by IS supporters was \#AIIEyesOnISIS [26].

The basic recipients of propaganda are people who speak Arabic, therefore, most of them appear in this language (e.g., newspapers/bulletins Al-Nabā and AlMasrā). Nevertheless, Al-Hayat also published magazines in other languages: French-Dar Al-Islam, Russian-Istok or Turkish-Konstantiniyye. However, from mid-2014 until mid-2016, the flagship online magazine was the Englishlanguage Dabiq ([27], pp. 74-75), [28]. Between July 5, 2014 to July 31,2016 , IS produced fifteen issues of that magazine. Its content refers not only to ideological aspects, but also appeals to the Muslim community, reports on expansion, terrorist attacks, and even interviews. With the loss of the city of Dabiq in October 2016, it was replaced by the Rumiyah. First number was issued on September 2016 and since then it appeared as a monthly until October 2017 ([29], p. 2). Rumiyah was translated into 10 languages: English, Bahasa, Bosnian, French, German, Kurdish, Pashto, Russian, Turkish and Uyghur, to broaden the range of supporters. It was shorter than Dabiq (the average number of pages was: 61 , while Rumiyah 45 ). Similar to Dabiq, this article included themes related to: religiosity and interpretation of Islam, responsibilities of mujahedeen, women and supporters, enemies, martyrs, instructions on how to carry out terrorist attacks ([29], pp. 4-5). The majority of the issues also contained interviews. The loss of the IS-controlled city of Raqqa in September 2017 forced IS to cease publication. Since then, Rumiyah has not been replaced by new magazine ([30], p. 249).

\section{Women of the Self-Proclaimed Caliphate}

In the past, women were seen as wives and mothers. However, in the last decades, terrorist groups started to see women beyond procreation. Cragin and Daly (2009) [31] identified five general roles (divided into subcategories) that women played in terrorist groups. First is the role of logisticians that involves basic tasks, such as couriers, protectors, and decoys. It is most common as it tends to be considered less dangerous and therefore appropriate. Second role of a recruiter was divided by the authors into three subcategories-facilitator, propagandist, and historical conscience. The next role is the operational leader and fighter, considered as quite rare in terrorist activity, more frequent in left-wing groups. Fourth role was connected to suicide terrorism, which attracts wide media attention (See [31]). Although this research was conducted prior to the peak of IS expansion, it seems that the roles have not changed. Only the centre of gravity, and therefore the division of roles, was shifted.

Gender difference as a constitutive variable is of key importance in studies on terrorism and counterterrorism (See more: [32]). An expression of the jihadi ideological expansion is the apparent control and compliance with the structure of gender roles in society. In its opinion, IS does not devalue the role of women. It adheres to highly defined and structured gender roles. In the right context, it highlights "positive (e.g., chaste, strong, pious, brave)" or "negative (e.g., promiscuous, immoral, deceiving) traits and values" to correspond with the right archetypes and "to distinguish each as part of either the in-group or the out-group" [33]. IS in fact-in the right context-values women and views their role as essential to the self-styled caliphate and the continuation of jihad. The introduced principles sanction their role 
in society, at the same time strengthening extremely patriarchal social norms. The institution that controls compliance with laws and morals is the religious police (Al-Hisba) [34]. A right to punish the disobedient was also implemented by the female brigade-Al-Khansa. In 2015, it published in Arabic, a document titled Women of the Islamic State: Manifesto and Case Study. It is believed to be the first document with a guideline for women (Quillam Foundation).

IS views women mainly via their role as mothers who build ummah [35], by giving birth to children who will become jihadists ([36], p. 41). Girls learn from an early age how to care for the needs of their future husbands and raise children in accordance with the ideology of Salafijihadism (more on the role of children ee ([37], pp. 1-20), [38]. IS also enslaves women. During the territorial expansion, slavery has become popular among the so-called foreign fighters $[39,40]$. The issue of slavery was presented in the pamphlet entitled "Questions and Answers on Taking Captives and Slaves" (Su'al wa-Jabab fi al-Sabi wa-Rikab) published in 2015 [41]. It sets out the conditions for women trafficking, as well as guidelines for sexual intercourse with slaves. Numerous reports tell about the methods on luring women. An example is a book by a French journalist, who decided to play the role of a young girl ready to join the jihadists (See [42]). The primary role of women is to protect home and family. However, women can also be useful as a warriors, because "female terrorists kill on average four times more people than their male counterparts" (See [43]). Jihadists use women next to men as the perpetrators of terrorist attacks to enrich their fighting techniques and counter antiterrorism efforts [44]. They seem to be better at remaining undetected; for example, by crossing the border checkpoints or hiding weapons in clothing.

Therefore, IS uses religion to justify its subjugation of women in contradictory ways. At the same time, it is used to justify sexual slavery and greater freedoms for women who travel on their own to IS's territories (On motives see: ([45], pp. 10-14)). On the other hand, later it is used to justify limitations on the basic movements of women living Islamic State' s territories. Hence the attribution of certain traits culturally perceived as feminine or masculine may be subject to modification in propaganda activity over time. Predispositions reflecting stereotypical approach to gender may be important at the stage of propaganda and recruitment, and not automatically reflect the real women position.

\section{Analysis and Discussion of Dabiq Content}

From mid-2014 until mid-2016, the flagship online magazine that targeted English speaking audiences was Dabiq. Between July 5, 2014, to July 31, 2016, Al-Hayat Media Center produced fifteen issues of that magazine, the leading quote of which was: "The spark has been lit here in Iraq, and its heat will continue to intensify-by Allah's permission-until it burns the crusader armies in Dabiq".

Issues 1-3, 5-7, 11, and 14 contain less than 20 keywords, mostly in sections Article (18), To Our Sisters (13), and Feature (10) (see Table 1).

The subjects of the articles and other sections of these issues do not directly relate to the role of women and girls, except one mention. It is a figure in News section entitled "Hadd of stoning" carried out on a woman for committing adultery ([46], p. 36).

The first article on the role of women in Dabiq appears in issue 4. It is entitled 'The Revival of Slavery Before the Hour.' It contains 23 keywords, of which 8 concern girl/girls (this is the largest content related to young women in Dabiq). The article deals with the issue of slavery, referring to the division into believers and infidels, recognizing Yezidi as a subordinate group ([39], pp. 14-17). Moreover, IS justifies sex crimes, particularly against Yazidi women. Other keywords in Issue 4 are located in five other sections ([39], p. 2).

In Issue 7, noteworthy is the article in section To Our Sisters 'A Brief Interview with Umm [47] Basīr al-Muhājirah' , who is a 26-year-old French citizen and a wife of Abū Basīr al-Ifrīii (Amedy Coulibaly), killed by police, following the shootings at the kosher supermarket in Paris on 9 January 2015. In the interview, she presents the advice to other Muslim women, praising the Islamic State and standard of living in Syria: "My sisters, be bases of support and safety for your husbands, brothers, fathers, and sons. Be advisors to them. They should find comfort and peace with you. Do not make things difficult for them. Facilitate all matters for them ([48], pp. 50-51)."

In the next issues, the largest number of keywords was found in the sections From Our Sisters/ To Our Sisters/ For Women (excluding issue 14). The largest number was most found in the section To Our Sisters 'The Twin Halves of the Muhājirīn' (16). The article by Umm Sumayyah alMuhayirah refers to the issue of hijrah, which is "migrating from the places of shirk and sin to the land of Islam and obedience." The author urges to come to the caliphate: "I met a sister who was six months pregnant accompanied by her husband coming from Britain. I was surprised by this adventurist, so I said, 'Why didn't you wait a bit until you gave birth to the baby you are carrying and then perform hijrah!' She answered, 'We could not handle waiting any longer. We melted yearning for the Islamic State!" According to Dabiq, migrating to the self-proclaimed caliphate is an obligation upon women (the twin halves of men) just as it is upon men ([24], p. 2). Other keywords were located in four other sections. 
Table 1. The number of words related to women and girls used in the Dabiq magazine.

\begin{tabular}{|c|c|c|c|c|c|}
\hline $\begin{array}{l}\text { Issue } \\
\text { Num- } \\
\text { ber }\end{array}$ & Title & $\begin{array}{l}\text { Pages } \\
\text { number }\end{array}$ & $\begin{array}{l}\text { Publication } \\
\text { date }\end{array}$ & $\begin{array}{l}\text { Num- } \\
\text { ber of } \\
\text { words } \\
\text { used }\end{array}$ & Number of sections \\
\hline$\# 1$ & The Return of Khilafah & 26 & 5 VII 2014 & 4 & 2-Article (3); News (1) \\
\hline \#2 & The Flood & 44 & 27 VII 2014 & 7 & $\begin{array}{l}\text { 4-Foreword (1); Report (1); Feature (3); Wisdom (1) News } \\
\text { (1) }\end{array}$ \\
\hline \#3 & The Call to Hijrah & 42 & 10 VII 2014 & 5 & 3-Foreword (2); Report (1); The Enemy's Words (2) \\
\hline \#4 & The Failed Crusade & 56 & $11 \times 2014$ & 34 & $\begin{array}{l}\text { 5-Foreword (1); Statement (3); Article x2 (23); Feature (3); } \\
\text { Special (4) }\end{array}$ \\
\hline \#5 & $\begin{array}{l}\text { Remaining and } \\
\text { Expanding }\end{array}$ & 40 & $21 X I 2014$ & 1 & 1-Foreword (1) \\
\hline \#6 & $\begin{array}{l}\text { Al-Qa' idah of } \\
\text { Waziristan: A } \\
\text { Testimony From Within }\end{array}$ & 63 & 29 XII 2014 & 11 & 3-Report (1) Article x2 (6) Feature (4) \\
\hline \#7 & $\begin{array}{l}\text { From Hypocrisy to } \\
\text { Apostasy }\end{array}$ & 83 & 12 || 2015 & 17 & $\begin{array}{l}\text { 6-Article (5); From the Pages of History (1); To Our Sisters } \\
\text { (4); Report (3); Feature (1); Special x2 (3) }\end{array}$ \\
\hline \#8 & $\begin{array}{l}\text { Shari' ah Alone Will } \\
\text { Rule Africa }\end{array}$ & 68 & 30 III 2015 & 21 & $\begin{array}{l}\text { 5-Foreword (1); Article (1); To Our Sisters (16); Report (1); } \\
\text { Interview (2) }\end{array}$ \\
\hline \#9 & $\begin{array}{l}\text { They Plot and Allah } \\
\text { Plots }\end{array}$ & 79 & $21 \vee 2015$ & 36 & $\begin{array}{l}\text { 4-Foreword (1); Report (2); From Our Sisters (32) Interview } \\
\text { (1) }\end{array}$ \\
\hline$\# 10$ & $\begin{array}{l}\text { The Laws of All or the } \\
\text { Laws of Men }\end{array}$ & 79 & 13 VII 2015 & 23 & $\begin{array}{l}\text { 5-Article (2); From the Pages of History (4); From Our } \\
\text { Sisters (14); Feature (2); In the Words of the Enemy (1) }\end{array}$ \\
\hline$\# 11$ & $\begin{array}{l}\text { From the Battle of } \\
\text { Al-Ahzab to the War of } \\
\text { Coalitions }\end{array}$ & 66 & 9 IX 2015 & 16 & $\begin{array}{l}\text { 6-Foreword (1); Article x2 (3); To Our Sisters (9); Feature } \\
\text { (1); Interview (1); Last page message (1) }\end{array}$ \\
\hline$\# 12$ & Just Terror & 66 & 18 XI 2015 & 56 & $\begin{array}{l}\text { 3-To Our Sisters (51); Article x2 (2); In the Words of } \\
\text { the Enemy (3); }\end{array}$ \\
\hline$\# 13$ & $\begin{array}{l}\text { The Rafidah: From Ibn } \\
\text { Sa'ba to the Dajjal }\end{array}$ & 56 & $19 \mid 2015$ & 29 & $\begin{array}{l}\text { 6-Foreword (2); From the Pages of History (1); Amongst } \\
\text { the Believers are Men (1); To Our Sisters (20); Article } \\
\text { Rāfidah (3); Interview (2) }\end{array}$ \\
\hline \#14 & $\begin{array}{l}\text { The Murtadd } \\
\text { Brotherhood }\end{array}$ & 68 & 13 IV 2016 & 3 & 3-Article (1); From the Pages of History (1); Interview (1) \\
\hline \#15 & Break the Cross & 82 & 31 VII 2016 & 44 & $\begin{array}{l}\text { 6-For Women } \times 2 \text { (26); Article } \times 3 \text { (8); From the Pages of } \\
\text { History (3); Operations (1); Feature (5); Interview (1) }\end{array}$ \\
\hline
\end{tabular}

In Issue 9 it was the section From Our Sisters entitled 'Slave-Girls or Prostitutes?' (32) that consisted the largest number of keywords. It is another Dabiq article that justifies the enslavement of women. Article by Umm Sumayyah AlMuhajirah defends the practice of taking women captured in war: "The right hand's possession (mulk al-yamin) are the female captives who were separated from their husbands by enslavement. They became lawful for the one who ends up possessing them even without pronouncement of divorce by their harbi husbands." Then the author tries to justify enslavement by comparison with prostitution in other countries: "Are slave-girls whom we took by Allah's command better, or prostitutes (...) who are grabbed by quasi men in the lands of kufr where you live? A prostitute in your lands comes and goes, openly committing sin. (...) As for the slave-girl that was taken by the swords of men following the cheerful warrior (...), then her enslavement is in opposition to human rights and copulation with her is rape?! What is wrong with you? How do you make such a judgment? What is your religion? What is you law?" ([49], pp. 44-49). The article also insults Michelle Obama, mentioning her as a prospect of being sold at a slave market, "And who knows, maybe Michelle Obama's price won't even exceed a third of a dīnār, and a third of a dīnār is too much for her!" ([49], p. 49).

In the next issue, IS also remembers about female jihadi readers. In the section From Our Sisters entitled 'They are Not Lawful Spouses for One Another' (14) Umm Sumayyah al-Muhajirah, offers advice to women who are married to men that oppose IS (sahwat [50]). This eight-page article offers historical arguments illustrating how women play a significant role in the continued rise of the group. The article suggests that women can leave their apostate husbands, because it is their religious duty ([51], pp. 42-48). It also shows that women are crucial to the survival of its caliphate. In 2015, they were part of the strategic goal-expansion, as they were a key to the next generation of jihadists (reproductive function).

In Issue 11, most keywords were found in the section To Our sisters 'A Jihād Without Fighting'(25). In this arti- 
cle, childbearing is once again presented as central to the role of women. They are expected to guide their children, referred to as lion cubs, towards jihad. The author, Umm Sumaya al-Muhajirah says that: "the absence of an obligation of jihād and war upon the Muslim woman-except in defence against someone attacking her-does not overturn her role in building the Ummah, producing men, and sending them out to the fierceness of battle". The article also states that for mujāhidah (female jihadi) "the weapon (...) is good behaviour and knowledge" and "preparing the lion cubs of the Khilāfah" ([36], pp. 40-45).

In Issue 12, the most references to women was made in section To Our Sisters 'Two, Three, or Four' (51). At the same time, it is the article with the most keywords in Dabiq56. Its title refers to a Quranic verse that allows men to marry up to four wives. The Dabiq is again authored by a woman, Umm Summayyah al-Muhajirah, to bolster the argument from a female perspective. Women are informed that if their husband were to have another wife, they can find more time for themselves and children, as well as to pray and deepen their knowledge of Islam ([52], p. 2). In practice, the reproductive function is once again emphasized, which is necessary for the "production" of the next generation of jihadists.

In the next issue, Islamic State also does not ignore its female readers. This time it publishes a piece 'To Our Sisters: Advice on Ihdād' (20) with advice for widows of jihadists (those of ihdād-mourning their husbands). It focuses on the mourning of dead. In previous articles, jihadi Umm Summayyah for example, defended the rape of thousands of Yazidi girls and urged women to leave their apostate husbands ([53], pp. 24-26). Therefore, compared to previous articles, this piece lacks the emphasis on terror and killing.

The last issue of Dabiq, in the section For Women 'The Fitrah [54] of Mankind and the Near-Extinction of the Western Woman' (26) attacks Western concepts of feminism and urges Muslim women to push back against it ([55], pp. 2025). In the last issue, jihadi propaganda also used words: feminism ('Foreword', 2) and femininity ('For Woman', 1) ([55], p. 2).

Summarizing the Dabiq content analysis, most words related to women and girls were found in Issue 12 Just Terror-70, however, the largest number of sections (articles) has been used in Issues 7 and 13. The most references were found in section 'To Our Sisters' (140). At the same time, the highest number of words in each issue was usually found in this section (5/15). However, the most frequently used section was 'Articles' (see table 2).

The number of words related to women and girls found in the magazine, indicates that they play and important roles in the IS structure. The most frequently discussed topics were: hijrah, marriage, motherhood, and slavery.

\section{Analysis and Discussion of Rumiyah Content}

The covers of Rumiyah contrast with those of Dabiq. The six issues have no title and the cover page includes the name of the magazine, the number of the issue, and the table of contents. Each cover has a dominant image which associates with articles. The leading quote of the magazine is from Abu Hamzah al-Muhajir (Abu Ayyub al-Masri): "O muwahhidin (believers in tawhid: the absolute oneness of Allah), rejoice, for by Allah, we will not rest from our jihad except beneath the olive trees of Rumiyah (Rome)" ([27], pp. 74-75).

Issues 2, 6, 7, 8, 10, and 13 contain less than 20 words related to women and girls, mostly in sections: Article (27) and Sisters (25) (see table 3). Among these issues, the article 'The Flesh of You Spouse is Poisonous' deserves attention (15). It is a marriage advice. The article states that no matter how many wives a jihadist may have, they must not talk about their private relationships. It warns that even worse than a gossiping wife is "man speaking about the secrets of his home to others" and moreover shows a "lack of manliness." ([56], p. 2).

An important article on the role of women in the caliphate appears already in the first issue. It is entitled ' $O$ Women, Give Charity' (18) ([57], pp. 18-20). The author states that women can wage jihad by donating to the cause, especially by carrying out non-combative services such as healthcare. Despite focusing on the nonmilitary aspect, it adds that women are obligated to fight if the enemy attacks and furthermore that they do not require their husbands' consent ([57], p. 2).

The next issue raises female themes in 'Article' and 'Exclusive' sections. Most words were found in the article entitled 'Abide in Your Homes'(38) which encourages women to remain at home and be looked after by her husband. Men are instructed that it is their duty to enforce restrictions on their wives, for example, if they leave home too frequently. The article presents this state as natural, in practice, it is an expression of a patriarchal framework and masculine dominance over women ([58], pp. 40-41).

In the next issue, IS also remembers about female readers. Issue 4 highlights the problem of marrying widows. The article entitled 'Marrying Widows is an Established Sunnah' (30), which encourages widows on jihadi fronts to remarry after losing a husband ([59], pp. 40-41). 
Table 2. The number of keywords and sections used in the Dabiq magazine.

\begin{tabular}{|c|c|c|}
\hline Section & Number of words & Number of sections \\
\hline Cover & 0 & 0 \\
\hline Table of Contents & 0 & 0 \\
\hline Amongst the Believers are Men & 1 & 1 \\
\hline Article & 57 & 17 \\
\hline Breaking News/News & 2 & 2 \\
\hline Enemy's Words/ In the Words of the Enemy & 6 & 3 \\
\hline Fatwa & 0 & 0 \\
\hline For Women & 26 & 1 \\
\hline Foreword & 10 & 8 \\
\hline Feature & 19 & 7 \\
\hline From Our Sisters & 46 & 2 \\
\hline Hikmah (Wisdom & 1 & 1 \\
\hline History/From the Pages of History & 10 & 5 \\
\hline Interview & 8 & 6 \\
\hline Last page message & 1 & 1 \\
\hline Operations/Military Operations & 1 & 1 \\
\hline Report & 9 & 6 \\
\hline Shuhada & 0 & 0 \\
\hline Special & 7 & 2 \\
\hline Statement & 3 & 1 \\
\hline To Our Sisters & 100 & 5 \\
\hline Jointly & 307 & 69 \\
\hline
\end{tabular}

Table 3. The number of words related to women and girls used in the Rumiyah magazine.

\begin{tabular}{|c|c|c|c|c|c|}
\hline $\begin{array}{l}\text { Issue } \\
\text { Num- } \\
\text { ber }\end{array}$ & Title & $\begin{array}{l}\text { Pages } \\
\text { number }\end{array}$ & $\begin{array}{l}\text { Publication } \\
\text { date }\end{array}$ & $\begin{array}{l}\text { Num- } \\
\text { ber of } \\
\text { words } \\
\text { used }\end{array}$ & Number of sections \\
\hline$\# 1$ & Rumiyah issue 1 & 38 & $5 \mathrm{IX} 2016$ & 21 & 1 -Article $\times 3(21)$ \\
\hline \#2 & Rumiyah issue 2 & 38 & $4 \times 2016$ & 19 & 2-Foreword (4); Article x2 (15) \\
\hline \#3 & Rumiyah issue 3 & 46 & 11 XI 2016 & 41 & 2-Exclusive (1); Article x2 (40) \\
\hline \#4 & Rumiyah issue 4 & 40 & 7 XII 2016 & 35 & 2-Exclusive (1); Article (34) \\
\hline \#5 & Rumiyah issue 5 & 44 & $6 \mid 2017$ & 40 & $\begin{array}{l}\text { 5-Exclusive x2 (22); Interview (2); Article x2 (6); Sisters (9); } \\
\text { News (1) }\end{array}$ \\
\hline \#6 & Rumiyah issue 6 & 44 & 4 II 2017 & 7 & 2-Article $\times 3$ (4); Sisters (3) \\
\hline \#7 & Rumiyah issue 7 & 38 & II 2017 & 17 & 3-Foreword (1); Exclusive (1); Sisters/Article (15) \\
\hline \#8 & Rumiyah issue 8 & 48 & 5 IV 2017 & 10 & 3-Exclusive (1); Sisters (6); Article (3) \\
\hline \#9 & $\begin{array}{l}\text { The Ruling on the } \\
\text { Belligerent Christians }\end{array}$ & 58 & $4 \mathrm{~V} 2017$ & 20 & 3-Table of Content (1); Feature (10); Sisters/Article (9) \\
\hline$\# 10$ & The Jihad in East Asia & 46 & 7 VI 2017 & 11 & 2-Article (2); Sisters (9) \\
\hline$\# 11$ & $\begin{array}{l}\text { The Ruling of } \\
\text { Ghanimah, Fay and } \\
\text { Ihtitab }\end{array}$ & 60 & 13 VII 2017 & 23 & $\begin{array}{l}\text { 6-Article (5); Sisters (12); Exclusive (1); Feature (1); } \\
\text { Military and Covert Operations (2); Shuhada (2); }\end{array}$ \\
\hline \#12 & $\begin{array}{l}\text { It Will be a Fire that } \\
\text { Burns the Cross and its } \\
\text { People in Raqqah }\end{array}$ & 46 & 6 VIII 2017 & 60 & $\begin{array}{l}\text { 4-Contents (1); Foreword (3); Article x4 (12); Sisters } \\
\text { (44) }\end{array}$ \\
\hline$\# 13$ & $\begin{array}{l}\text { Allah Cast Terror into } \\
\text { their Hearts }\end{array}$ & 44 & 9 IX 2017 & 5 & 2-Foreword (1); Article x4 (4) \\
\hline
\end{tabular}


Although the problems of jihadi widows were raised in Dabiq, Rumiyah illuminates it in a completely different light.

Issue 5 in Exclusive section entitled 'Collateral Carnage' (21) raises the problem of killing innocent people, stating that: "one should not grieve over the collateral killing of kafir women and children". It further states that "kafir women and children who do not fight or otherwise partake in hostilities (...) should not be deliberately killed, meaning that one should not single them out for targeting. However, when they are not distinctly isolated from the kafir men or when they are not easily distinguishable from them, then their collateral killing is a justified part of the jihad against the kuffar." ([60], pp. 6-7). Other important references were located in section Sisters 'I Will Outnumber the Other Nations Through You' (9). The article again raises the issue of reproduction; it is an encouragement to have a lot of children. The author suggests that the best thing women can do is have children, as that will help to conquest of the world ([33], p. 27) ([60], pp. 2, 34-34).

In Issue 9, a similar number of keywords was found in two sections: Feature 'The Ruling on the Belligerent Christians' (10) and Article 'The Woman Is a Shepherd in Her Husband's Home and Responsible for Her Flock' (9). This Issue opens with a Feature section, which strongly justifies recent controversial, anti-Christian terror tactics-the bombing of churches. It also calls to kill anyone who carries a weapon "regardless of whether they are a child or a woman" ([61], pp. 4-10). Second of the aforementioned sections once again states that a woman's role is to "remain in her home." Outlining mothers as shepherds of their families, the author emphasized that there were five central aspects to motherhood. The first is based on tawhid (monotheism)ideological preparation of children for combat. The second comes to 'being an example' to those in their flock. Next is an obligation to prepare their offspring for the hardships of life in a state of war. Then mothers have to encourage their children to engage in the fight and aspire to martyrdom. Finally, the ideal jihadi mother should "ensure that her children speak the Arabic language and ensure that their Arabic is correct and free of linguistic errors", which is especially addressed to foreign fighters and their families ([61], pp. 18-21).

In Issue 11 in Section Sisters entitled 'Our journey to Allah', once again IS emphasizes that the role of women is of increased importance, as they must keep their husbands and children committed to the cause ([62], pp. 18-21). A similar message is noticeable in Issue 12 , in section Sisters 'The Female Slaves of Allah in the House of Allah' (44) argues that it is preferable for women to pray at home, as opposed to praying in a mosque. Again, Rumiyah underlines the necessity for women to stay at home ([63], p. 2).

In conclusion, most words in Rumiyah were found in Issue 12-60; however, the largest number of sections (articles) has been used in Issue 5. Most words were found in section 'Article'. At the same time, it was the most frequently used section, regarding women and girls (see table 4). The number of words related to women and girls found in the magazine, indicates that IS pays attention to female activity in its ranks. Analysis of Rumiyah content shows that role of women is seen from the perspective of the housewife. However, the new magazine, similarly to Dabiq, tends to show new roles where women also operate as recruiters or aggressors.

\section{Similarities and Difference in Dabiq and Rumiyah}

Thematically, both magazines contain a series of articles for women, written by women as well as interviews with female followers. Mentions of the role of women are omnipresent in the analysed magazines, which is confirmed by the number of keywords found. Distribution of words shows that in Dabiq the most popular sections were 'To Our Sisters' and 'Article' while in Rumiyah the interest in female related topics has shifted to 'Article' and 'Sisters' (see: Table 5). Interestingly, these two sections in Rumiyah combined $82 \%$ of keywords while in Dabiq it was only 44\%. In Dabiq, greater emphasis was placed on hijrah, marriage, motherhood, and slavery. The emphasis corresponds to increased expansion, when IS was trying to recruit new supporters. In contrast, Rumiyah creators started to use fewer sections, but it did not significantly decrease the number of words related to women and girls ( 0.5 words per page; Dabiq - 0.3 words). This drop did not show a correlation with the decrease in the number of pages (the average number of magazine pages was: Dabiq - 61, while Rumiyah - 45). Interesting is also the fact that the diversity of Rumiyah sections in which female themes were not touched was lower. In Dabiq, 17 out of 20 sections (81\%) touched upon the subject matter, while in Rumiyah it was 9 out of 9 (100\%) (see: Table 5). Therefore, despite decrease in the number of words per page, the percentage share was higher in the Rumiyah.

Table 4. The number of keywords and sections used in the Rumiyah magazine.

\begin{tabular}{lll}
\hline Section & $\begin{array}{l}\text { Number } \\
\text { of words }\end{array}$ & $\begin{array}{l}\text { Number } \\
\text { of } \\
\text { sections }\end{array}$ \\
\hline Cover & 2 & 2 \\
Article & $\mathbf{1 4 6}$ & $\mathbf{2 4}$ \\
Exclusive & 27 & 7 \\
Foreword & 9 & 4 \\
Feature & 11 & 2 \\
Interview & 2 & 1 \\
Last page message & 1 & 1 \\
News: operations/ News: military & 3 & 2 \\
and covert operations & & 1 \\
Shuhada & 2 & 8 \\
Sisters & 107 & 51 \\
\hline Jointly & 309 & \\
\hline
\end{tabular}


Table 5. The number of keywords and sections used in the Rumiyah magazine.

\begin{tabular}{lll}
\hline Section & Dabiq & Rumiyah \\
\hline Cover/Table Contents & 0 & 2 \\
Article & $\mathbf{5 7}$ & $\mathbf{1 4 6}$ \\
Breaking News/ News & 2 & - \\
Enemy's Words/ In the Words of the & 6 & - \\
Enemy & & \\
Fatwa & 0 & - \\
For Women & 26 & - \\
Exclusive & - & 27 \\
Foreword/Introduction & 10 & 9 \\
Feature & 19 & 11 \\
From Our Sisters & 46 & - \\
Hikmah (Wisdom) & 1 & - \\
History & 10 & - \\
Interview & 8 & 2 \\
Last Page message & 1 & - \\
News Operations/ News military & 1 & 3 \\
and covert operations & & \\
Report & 9 & - \\
Sisters & - & 107 \\
Special & 7 & - \\
Shuhada & 0 & 2 \\
Statement & 3 & - \\
To Our Sisters & $\mathbf{1 0 0}$ & - \\
\hline Jointly & 307 & 309 \\
\hline
\end{tabular}

A theme which prevails in Dabiq is related to creating the feeling of empowerment of its female audience. It is highlighted by themes such as hijrah and the important role of wives, mothers, and sister in creating the caliphate. IS English messaging changed after replacement of Dabiq by Rumiyah. This event occurred in a difficult period for IS associated with territorial losses. Therefore, much of the content of the new magazine was filled with articles, for the most part translated into English from Arabic Al-Naba'. This resulted in a transformation in the English-language messaging. It seems that IS adopt the same demeaning descriptions of women that in the Arabic-language messaging that targeted mostly men, not women. This reflects the link between language and messaging.

\section{Conclusions}

In IS propaganda, masculine dominance intertwines with gender essentialism. Numerous articles stress the obligatory need for women to marry and then be looked after by their husbands. They take over this responsibility from male relatives (whether fathers, brothers, or other guardians). Women who disagree with that are opposing fitrah (human nature). On the other hand, a group that explicitly promotes women's subjugation offers women mock tools of empowerment.

In the analysed magazines, the voices of women, such as Umm Sumayyah al-Muhajirah are highlighted. They are highly assertive in defending sex slavery or urging women to support of fight under the black flag. These female propagandists in sections 'From Out Sisters', 'To Our Sisters', 'For Women's of the Dabiq and Rumiyah help to promote the interests of IS, not the empowerment of women itself. The inclusion of such a long and detailed article written by women members demonstrates that IS is interested in the potential of women (due to the language, mainly from the Western sphere). However, this is only a rubber stamp of care. In practice, articles are a way to lure women into the trap . In addition, they promote breaking the laws of women.

Dabiq was published during the consolidation of control (August 2014-January 2015), through gradual loss of control (January 2015-June 2016). When IS has entered the phase of struggle for survival (from June 2016), with the loss of Ar-Raqqa publication stopped. However, during the fall of the self-proclaimed caliphate (since July 2017), even when the coalition-backed campaign aimed at recapturing Mosul was at its fiercest, the new magazine-Rumiyah urged their female readers to provide for their husbands, brothers, fathers, and sons. New magazine, consisting mostly of translations of articles from previous Al-Nabā issued in Arabic, presented demeaning descriptions of women. Articles like 'Abide in Your Homes' or 'Marrying Widows Is an Established Sunnah' focus on women as support for jihad. It was up until September 2017. The loss of Ar-Raqqa forced to cease its publication. Since then, Rumiyah has not been replaced by a new magazine.

However, the territorial losses and manpower shortages created a need for change. The roles of female supporters were clear. They had to stay at home, take care of the family, rather than fight; having as many children as possible and remarrying another jihadist if their husband was killed. In turn, infidel women were to serve as slaves. Consistently, for years, these roles conform to the traditional jihadi reasoning regarding women and war. Jihadi mothers, wives, sisters, and daughters were a necessary part of jihadi project but rarely encouraged to engage in violence. This position seems to change. The extent to which women are being currently involved in fighting remains unclear. However, IS from the end of 2016 undeniably begun to recognize the role of women in armed struggle, as the abovementioned articles in Rumiyah indicate. This turnaround is confirmed by increased female suicide bombings hiding among civilians in Iraq. The use of female suicide bombers in battle, while not new, was exceedingly rare. It seems that this shift could be related to the enriching the arsenal of the desperate group [64]. This observation is confirmed in the 1 Issue of Rumiyah, in the article 'O Women, Give Charity' ([57], pp. 18-20). Despite focusing on the nonmilitary aspect, it adds that women are obligated to fight if the enemy attacks. It is also presented in 'The Duty of Women in Waging Jihad against the Enemy', published in issue 100 of Al-Nabā. In general, women were called to prepare themselves as mujahidat (female warriors), "to fulfill their duty from all aspects in supporting the mujahideen in this battle" (See [65]). In crisis, losing territories, the IS directed its propaganda toward women, with a call for help. 


\section{Acknowledgments}

I would like to thank Siedlce University of Natural Sciences and Humanities for support of this research. I would also like to express my gratitude to two anonymous reviewers for

\section{References and Notes}

[1] Cunningham KJ. Cross-Regional Trends in Female Terrorism. Studies in Conflict \& Terrorism. 2003;26(3):171-195. doi:10.1080/10576100390211419.

[2] Chatterjee D. Gendering ISIS and Mapping the Role of Women. Contemporary Review of the Middle East. 2016;3(2):201-218. doi:10.1177/2347798916638214.

[3] Warner J, Matfess H. Exploding Stereotypes: The Unexpected Operational and Demographic Characteristics of Boko Haram's Suicide Bombers. New York, NY, USA: Combatting Terrorism Center at West Point; 2017. Available from: https://ctc.usma.edu/wpcontent/uploads/2017/08/Exploding-Stereotypes-1.pdf.

[4] Combating Terrorism Center report shows that from April 11, 2011 to June 30,2017 , Boko Haram used 434 suicide bombers to conduct 238 suicide attacks. At least $56 \%$ of the bombers were women.

[5] Speckhard A. The Emergence of Female Suicide Terrorists. Studies in Conflict \& Terrorism. 2008;31(11):995-1023. doi:10.1080/10576100802408121.

[6] Lahoud N. Empowerment or Subjugation: An Analysis of ISIL's Gendered Messaging. United Nations Women. 2018 June; Available from: https://www2.unwomen.org/-/media/field\% 20office\%20arab\%20states/attachments/publications/lahoud-finweb-rev.pdf?la $=$ en\&vs $=5602$.

[7] Windsor L. The Language of Radicalization: Female Internet Recruitment to Participation in ISIS Activities. Terrorism and Political Violence. 2018;32(3):506-538. doi:10.1080/09546553.2017.1385457.

[8] Nivat A. The Black Widows: Chechen Women Join the Fight for Independence-and Allah. Studies in Conflict \& Terrorism. 2005;28(5):413-419. doi:10.1080/10576100500180394.

[9] Dalton A, Asal V. Is It Ideology or Desperation: Why Do Organizations Deploy Women in Violent Terrorist Attacks? Studies in Conflict \& Terrorism. 2011;34(10):802-819. doi:10.1080/1057610x.2011.604833.

[10] Lavina R. Women in Terrorism: How the Rise of Female Terrorists Impacts International Law. Connecticut Journal of International Law. 2015;30(2):241-263. Available from: https://heinonline.org/HOL/ LandingPage?handle=hein.journals/conjil30\&div=15\&id=\&page $=$

[11] Berger JM, Strathearn B. Who Matters Online. Measuring Influence, Evaluating Content and Countering Violent Extremism in Online Social Networks. 2013; Available from: https://icsr.info/wp-content/uploads/2013/03/ICSR-Report-WhoMatters-Online-Measuring-influence-Evaluating-Content-andCountering-Violent-Extremism-in-Online-Social-Networks.pdf.

[12] Silverman D. Interpreting Qualitative Data. Methods for Analysing Talk, Text and Interaction. Sage Publications; 1993.

[13] Stern J, Berger JM. ISIS. The State of Terror. William Collins; 2015.

[14] Atwan AB. Islamic State: The Digital Caliphate. University of California Press; 2015.

[15] Andersen JC, Sandberg S. Islamic State Propaganda: Between Social Movement Framing and Subcultural Provocation. Terrorism and Political Violence. 2018;doi:10.1080/09546553.2018.1484356.

[16] Welch T. Theology, Heroism, Justice, and Fear: An Analysis of ISIS Propaganda magazinesDabiqandRumiyah. Dynamics of Asymmetric Conflict. 2018;11(3):186-198. doi:10.1080/17467586.2018.1517943.

[17] Lakomy M. Recruitment and Incitement to Violence in the Islamic State's Online Propaganda: Comparative Analysis of Dabiq and Rumiyah. Studies in Conflict \& Terrorism. 2019;44(7):565-580. doi:10.1080/1057610x.2019.1568008.

[18] Matusitz J, Madrazo A, Udani C. Online Jihadist Magazines to Promote the Caliphate. Peter Lang US; 2019. doi:10.3726/b15002.

[19] Women in Islamic State Propaganda: Roles and Incentivites. Europol; 2019. Available from: https://www.europol.europa.eu/activitiesservices/europol-specialist-reporting/women-in-islamic-statepropaganda. their thoughtful and helpful suggestions and particular gratitude to Estefania de la Garza and the entire editorial team for providing kind assistance during the entire publishing process.

[20] Khelghat-Doost H. Women of the Caliphate: The Mechanism for Women's Incorporation Into the Islamic State (IS). Perspectives on Terrorism. 2017;11(1):17-25. Available from: http://www. terrorismanalysts.com/pt/index.php/pot/article/view/574/1130.

[21] Sjøberg-Aasgaard A. Migrants, Housewives, Warriors or Sex Slaves: AQ's and the Islamic State's Perspectives on Women. Connections: The Quarterly Journal. 2017;16(1):100-112. doi:10.11610/connections.16.1.08.

[22] Zelin AY. Picture Or It Didn't Happen: A Snapshot of the Islamic State's Official Media Output. Perspectives on Terrorism. 2015;9(4):85-97. Available from: http://www.terrorismanalysts.com/ pt/index.php/pot/article/view/445/876.

[23] York R. Know The Enemy: Islamic State of Iraq and the Levant. Lulu.com; 2015.

[24] Dabiq Issue 8. Available from: http://media.clarionproject.org/files/ islamic-state/isis-isil-islamic-state-magazine-issue+8-sharia-alonewill-rule-africa.pdf.

[25] Klausen J. Tweeting theJihad: Social Media Networks of Western Foreign Fighters in Syria and Iraq. Studies in Conflict \& Terrorism. 2014 Dec;38(1):1-22. doi:10.1080/1057610x.2014.974948.

[26] \#AllEyesOnISIS. Twitter; 2015. Available from: https://twitter.com/ hashtag/alleyesonisis.

[27] Alexander Y, Alexander D. The Islamic State: Combating The Caliphate Without Borders. Lexington Books; 2015.

[28] Dabiq is a small town in the northern province of Aleppo, in Syria, on the border with Turkey. The location is also of historical importance. In 1516 there was a decisive battle between the Ottoman Empire and the Mamluks, which ended with a victory of the Empire. As a result of this clash, the last recognized caliphate was consolidated.

[29] Wignell P, Tan S, O'Halloran KL, Lange R. A Mixed Methods Empirical Examination of Changes in Emphasis and Style in the Extremist Magazines Dabiq and Rumiyah. Perspectives on Terrorism. 2017;11(2):2-20. Available from: http://www.terrorismanalysts.com/ pt/index.php/pot/article/view/592/1169.

[30] Bröckling M, Fritsch C, Haider M, Yalman T. "Kill Them Wherever You Find Them" - Radicalizing Narratives of the "So-Called" Islamic State Via the Online Magazine Rumiyah. Journal for Deradicalization. 2018;pp. 240-294. Available from: http://journals.sfu.ca/jd/index.php/ jd.

[31] Cragin RK, Daly SA. Women as Terrorists: mothers, recruiters, and martyrs. ABC-CLIO, LLC.; 2009. Available from: http://www. hurstpublishers.com/book/bombshell/.

[32] Gasztold A. Feminist Perspectives on Terrorism. Springer International Publishing; 2020. doi:10.1007/978-3-030-37234-7.

[33] Ingram HJ. Islamic State's English-language Magazines, 2014-2017: Trends \& Implications for CT-CVE Strategic Communications. Terrorism and Counter-Terrorism Studies. 2018;doi:10.19165/2018.1.03.

[34] Moavenif A. For ISIS Women, Fraught Choices. New York Times. 2017 Nov 22; Available from: https://www.nytimes.com/2015/11/ 22/world/middleeast/isis-wives-and-enforcers-in-syria-recountcollaboration-anguish-and-escape.html.

[35] Arabic word form "community".

[36] Dabiq Issue 11. Available from: http://www.clarionproject.org/ docs/Issue\%2011\%20-\%20From\%20the\%20battle\%20of\%20AlAhzab\%20to\%20the\%20war\%20of\%20coalitions.pdf.

[37] Horgan JG, Taylor M, Bloom M, Winter C. From Cubs to Lions: A Six Stage Model of Child Socialization into the Islamic State. Studies in Conflict \& Terrorism. 2016;40(7):645-664. doi:10.1080/1057610x.2016.1221252.

[38] Benotman N, Malik N. The Children of Islamic State; 2016. Available from: https:/f.hypotheses.org/wp-content/blogs.dir/2725/files/2016/ 04/the-children-of-islamic-state.pdf.

[39] Dabiq Issue 4. Available from: http://media.clarionproject.org/ files/islamic-state/islamic-state-isis-magazine-Issue-4-the-failed- 
crusade.pdf.

[40] Slavery in Islam: To have and to Hold. The Economist. 2014;11(3):4849. Available from: https://www.economist.com/middle-east-andafrica/2014/10/18/to-have-and-to-hold.

[41] Islamic State Releases Pamphlet On Female Slaves. MEMRI Jihad \& Terrorism Threat Monitor. 2014; Available from: https://www.memri. $\mathrm{org} / \mathrm{jttm} /$ islamic-state-isis-releases-pamphlet-female-slaves.

[42] Erelle A. Dżihadystka: relacja z wnętrza komórki rekrutacyjnej Państwa Islamskiego. Wydawnictwo Sonia Draga; 2015.

[43] Bloom M. Bombshell: The Many Faces of Women Terrorists. Hurst Publishers; 2011. Available from: http://www.hurstpublishers.com/ book/bombshell/.

[44] Mekhennet S, Warrick J. The Jihadist Plan to Use Women to Launch the Next Incarnation of ISIL. The Washington Post. 2017 Nov 26; Available from: https:/www.washingtonpost.com/world/nationalsecurity/the-jihadistplan-to-use-women-to-launch-the-nextincarnation-of-ISIL/2017/11/26/e81435b4-ca29-11e7-8321481fd63f174d_story.html?utm_term=.e5eb0be3c433.

[45] Hoyle C, Bradford A, Frenett R. Becoming Mulan? Female Western Migrants to ISIS. Institute for Strategic Dialogue; 2015. Available from: https://www.isdglobal.org/wp-content/uploads/2016/02/ ISDJ2969_Becoming_Mulan_01.15_WEB.pdf.

[46] Dabiq Issue 2. Available from: http://media.clarionproject.org/files/092014/isis-isil-islamic-state-magazine-Issue-2-the-flood.pdf.

[47] Arabic word meaning mother.

[48] Dabiq Issue 7. Available from: https://clarionproject.org/docs/islamicstate-dabiq-magazine-issue-7-from-hypocrisy-to-apostasy.pdf.

[49] Dabiq Issue 9. Available from: https://clarionproject.org/docs/isisisil-islamic-state-magazine-issue+9-they-plot-and-allah-plots-sexslavery.pdf.

[50] Sahwat is the term describing Sunnis who fights against brothers on behalf of the West, Shi'a, and other forces, or collaborate with government against IS.

[51] Dabiq Issue 10. Available from: https://jihadology.net/2015/07/13/al$\%$ e1\%b8\%a5ayat-media-center-presents-a-new-issue-of-the- islamic-states-magazine-dabiq-10/.

[52] Dabiq Issue 12. Available from: http://www.clarionproject.org/ docs/Issue\%2011\%20-\%20From\%20the\%20battle\%20of\%20AlAhzab\%20to\%20the\%20war\%20of\%20coalitions.pdf.

[53] Dabiq Issue 13. Available from: https://jihadology.net/2016/01/19/ new-issue-of-the-islamic-states-magazine-dabiq-13/.

[54] Fitrah - human nature or instinct.

[55] Dabiq Issue 15. Available from: http://clarionproject.org/wpcontent/uploads/islamic-state-magazine-dabiq-fifteen-breakingthe-cross.pdf.

[56] Rumiyah Issue 7. Available from: http:// qb5cc3pam3y2ad0tm1zxuhho-wpengine.netdna-ssl.com/wpcontent/uploads/2014/09/Rumiyah-issue-seven.pdf.

[57] Rumiyah Issue 1. Available from: https://azelin.files.wordpress.com/ 2016/09/rome-magazine-1.pdf.

[58] Rumiyah Issue 3. Available from: https://azelin.files.wordpress.com/ 2016/11/rome-magazine-3.pdf.

[59] Rumiyah Issue 4. Available from: http:// qb5cc3pam3y2ad0tm1zxuhho-wpengine.netdna-ssl.com/wpcontent/uploads/2014/09/Rumiyah-ISIS-Magazine-4th-issue.pdf.

[60] Rumiyah Issue 5. Available from: http:// qb5cc3pam3y2ad0tm1zxuhho-wpengine.netdna-ssl.com/wpcontent/uploads/2014/09/Rumiyah-ISIS-Magazine-5th-issue.pdf.

[61] Rumiyah Issue 9. Available from: https:// qb5cc3pam3y2ad0tm1zxuhho-wpengine.netdna-ssl.com/wpcontent/uploads/2017/05/Rumiyah-9.pdf.

[62] Rumiyah Issue 11. Available from: https://jihadology.net/2017/07/13/ new-release-of-the-islamic-states-magazine-rome-11/.

[63] Rumiyah Issue 12. Available from: https://jihadology.net/2017/08/06/ new-release-of-the-islamic-states-magazine-rome-12/.

[64] Ensor J. Chilling Picture Shows Female Isil Fighter Holding Child Moments before Detonating Suicide Vest. Daily Telegraph. 2017;

[65] Al-Nabā. Issue 100. Available from: http://sitemultimedia.org/docs/ SITE_IS_Naba100.pdf. 